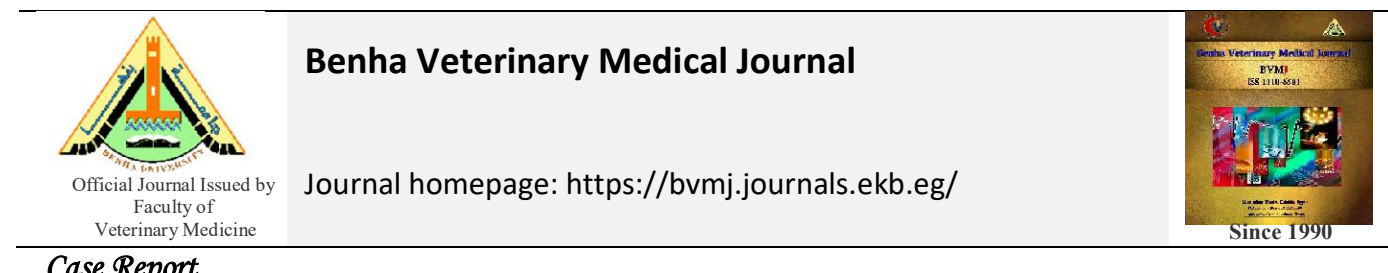

Case Report

\title{
Bronchiolitis Obliterans in Dromedary camel (one-humped) in Aswan Slaughter houses, Egypt
}

Marwa A. Ahmed

Department of Pathology, Faculty of veterinary Medicine, Aswan University, Egypt

\begin{tabular}{|c|c|}
\hline ARTICLE INFO & ABSTRACT \\
\hline \multicolumn{2}{|l|}{ Keywords } \\
\hline $\begin{array}{l}\text { Case report } \\
\text { bronchiolitis obliteran } \\
\text { Histopathology }\end{array}$ & $\begin{array}{l}\text { Respiratory disorders in camels are very common and often cannot be easily identified in live } \\
\text { animals until complicated. Thus, the only way to understand the pathology behind respiratory } \\
\text { disorders and their prompt diagnosis is by examining lungs at slaughter. So, this study was } \\
\text { designed to describe bronchiolitis obliterans in camel when reported as case report. } \\
\text { Bronchiolitis obliterans is a form of rare pulmonary disease. It happens when tiny airways in } \\
\text { the lungs, called bronchioles, are scarred. This scarring makes it difficult for the air to flow } \\
\text { and for the animals to breathe, causing the airways to narrow. Lung biopsy can be the best } \\
\text { way to diagnosis bronchiolitis obliterans. Thus, during post-slaughter inspection of } \\
\text { dromedary camels (Camelus dromedaries) slaughtered at the Draw Abattoir, Aswan, Egypt, } \\
\text { one case of bronchiolitis obliterans in adult camel was reported. Histopathological features } \\
\text { revealed intra-luminal polyps of inflammatory granulated tissues that obstruct small airways. } \\
\text { In addition, regions of emphysema were located in the neighboring alveoli and some of them }\end{array}$ \\
\hline $\begin{array}{l}\text { Received 19/09/2020 } \\
\text { Accepted22/04/2021 } \\
\text { Available On-Line }\end{array}$ & $\begin{array}{l}\text { were packed with exudate. Finally, it can be concluded that bronchiolitis obliterans occur in } \\
\text { one humped camel. }\end{array}$ \\
\hline
\end{tabular}

\section{INTRODUCTION}

In camels, respiratory diseases can cause significant economic losses through production loss, treatment costs, carcass condemnation and even death of infected animals (Zubair et al., 2004; Kane et al., 2005; Bekele, 2008; Abubakar et al., 2010).

Most early bronchiolitis obliterans descriptions were limited to case reports with autopsy results. Before open lung biopsy, a more traditional approach was used to describe earlier pathological findings.

Bronchiolitis obliterans started with bronchiolar epithelium injury after an inflammatory reaction that progressed towards airway fibrosis and luminary capacity obstruction (Kurland and Michelson, 2005).

\section{CASE HISTORY}

During inspection of camel slaughtered in the Abattoir Draw, Aswan, Egypt. The lung tissues specimens were brought for histopathological analysis to Aswan University,
Faculty of Veterinary Medicine and Department of Pathology. Histopathological tissue samples were fixed in $10 \%$ neutral buffered formalin, routinely handled, $5-\mu \mathrm{m}-$ sectioned and stained with Hematoxylin and Eosin (HE) (Bancroft and Stevans, 1993).

\section{RESULT}

One case was identified microscopically as bronchiolitis Obliterans. In the lumen of bronchiole, bronchiolitis obliterans was observed and appeared as a polyp in which organized exudates formed by connective tissue and infiltration of lymphocytes covered by hyperplastic respiratory epithelium attached to the bronchiolar wall (Fig. 1A-1B).

Another tiny bronchiole also showed obliterans bronchiolitis (Fig.2). In addition, the neighboring alveoli exhibited emphysema areas (Fig.2) and some of them were filled with exudate (Fig.1A).

* Corresponding author: marwaahmad78@yahoo.com 


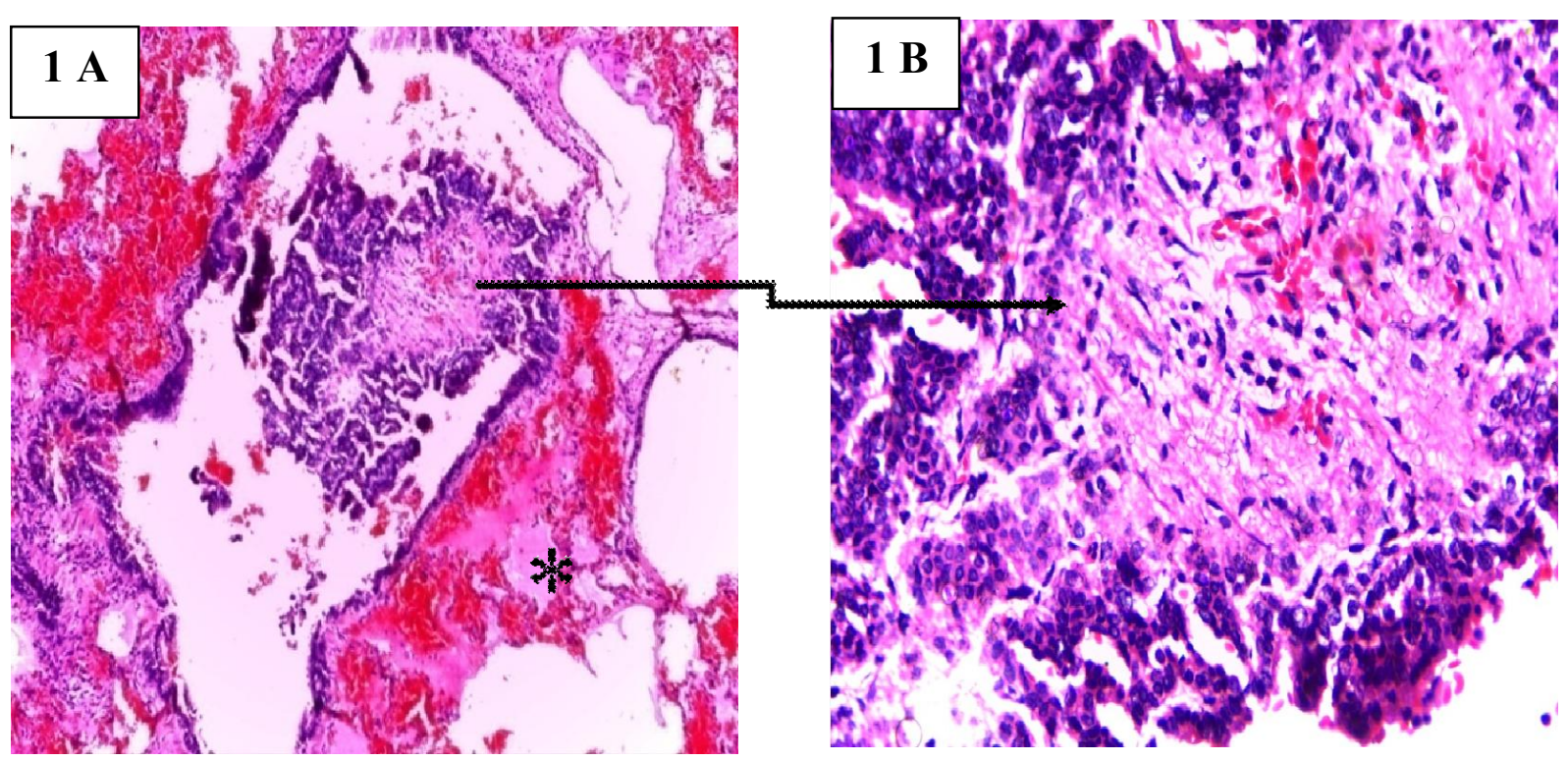

Figure 1 A Camel lung showing bronchiolitis obliterans, revealed by the presence of a polyp of granulation tissue covered by a hyperplastic respiratory epithelium attached to the bronchiolar wall and blocked the bronchiole. Exudates filled the neighboring alveoli (asterisk *). H \& E stain 10X25.

Fig.1B: High magnification of the intra-luminal polyp in which the hyperplastic respiratory epithelium covers the organized exudate through connective tissue and lymphocyte infiltration. $\mathrm{H} \& \mathrm{E}$ stain $10 \mathrm{X} 40$.

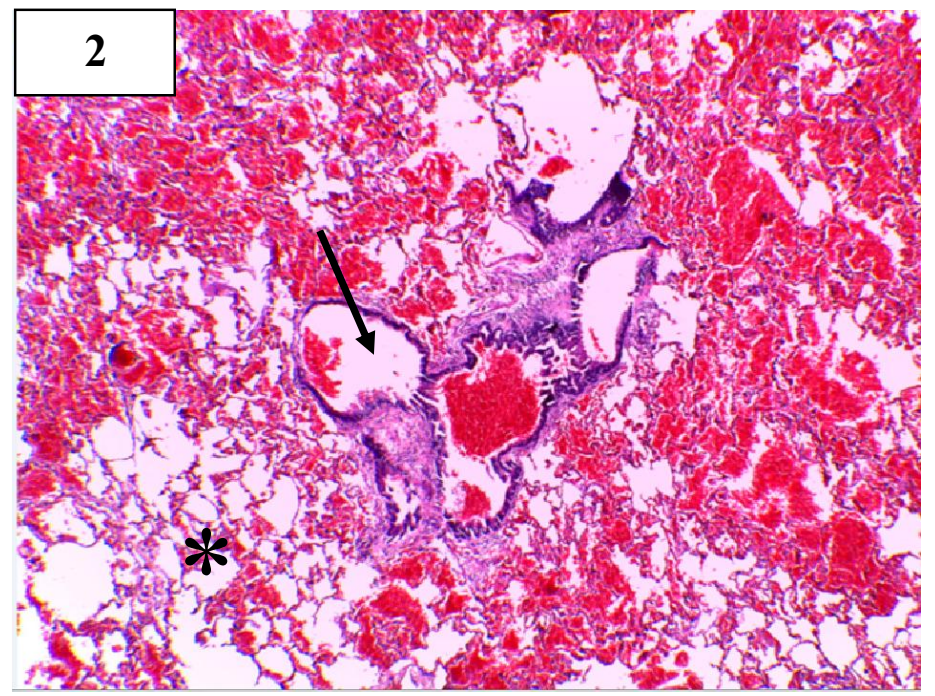

Figure 2 Bronchiolitis obliterans has been demonstrated in another small bronchiole (arrow $\searrow$ ). The adjacent alveoli exhibited areas of emphysema (asterisk *). H \& E stain $10 \mathrm{X} 10$.

\section{DISCUSSION}

To our knowledge, bronchiolitis obliterans has not been recorded before occurring in camels. In this study, one case of bronchiolitis obliterans with intraluminal polyp in camel was reported. Similar findings were published by Cheng et al., 2011 who reported that bronchiolitis obliterans organizing pneumonia (BOOP) in domestic pigs. Typical intraluminal Plugs showed in five porcine lungs with Type 2 natural porcine circovirus pneumonia (PCV2). In addition, Wylie et al., 2019 reported constrictive bronchiolitis obliterans in the dog.

Bronchiolitis obliterans is probably described as common pathological alteration of small airways after the various diseases with varying aetiologies. The initial insult, the inflammatory localized and pre-existing factors including nutrient status and genetic variants are considered to influence the process which finally results in the pathology observed in the small airways (Silvija-Pera Jerkic et al., 2020). Failure to resolve initial and ongoing inflammation could be a major part of the disease process in post infectious obliterans bronchiolitis. Immune and inflammatory cells and the proliferation of granulation tissue in the airways this leads to bronchial obstruction and epithelial changes such as atrophy or hyperplasia (Poletti et al., 2015). Infections of the lower respiratory tract caused by acquired respiratory viruses have been reported to increase the risk of bronchiolitis obliterans (Vilchez et al., 2003; Neurohr et al., 2005). In addition, toxic gases have caused some instances of bronchiolitis obliterans (Kelly et al., 2014), chronic aspiration (Hardy et al., 1988) and 
certain drugs (Cooper and Matthay, 1987). Moreover, several etiologies have also been associated with animal bronchiolitis obliterans organizing pneumonia (BOOP) pathogenesis. Dogs experimentally infected with Adenovirus (Castleman, 1985; Quan et al., 1990), Mycoplasma (Kirchner et al., 1990), or clinically infected cattle with bovine respiratory syncytial virus pneumonia occasionally develop pneumonia-organizing bronchiolitis obliterans (Philippou et al., 2000). Intra-air exposure of dogs to non-infectious oleic acid caused bronchiolitis obliterans organizing pneumonia (Li et al., 2006).

\section{ACKNOWLEDGEMENTS}

Thanks to Dr. Wafaa Ahmad Aly (Ph.D. in forensic medicine and veterinary toxicology and manager of veterinary quarantine department of Assiut) for arrangement and submission .

\section{REFERENCES}

1. Abubakar, M.S., Fatihu, M.Y., Ibrahim, N.D.J., Oladele, S.B., Abubakar, M.B., 2010. Camel pneumonia in Nigeria: Epidemiology and bacterial flora in normal and diseased lung. African Journal of Microbiology Research 4:2479-2483.

2. Bancroft, J.D. and Stevans, A., 1993. Theory and practice of histologic techniques. 3rd Ed. Long Man Group limited. pp. 113-305.

3. Bekele, S.T., 2008. Gross and microscopic pulmonary lesions of camels from eastern Ethiopia. Tropical Animal Health and Production 40:25-28.

4. Castleman, W. L.,1985. Bronchiolitis obliterans and pneumonia induced in young dogs by experimental adenovirus infection. The American Journal of Pathology 119 (3): 495-504.

5. Cheng, C.C., Lee, Y.F., Lin, N.N., Wu, C. L., Tung, K.C., Chiu, Y.T., 2011. Bronchiolitis Obliterans Organizing Pneumonia in Swine Associated with Porcine Circovirus Type 2 Infection. Journal of Biomedicine and Biotechnology 2011:1- 9.

6. Cooper Jr., J. A. and Matthay, R.A.,1987. Druginduced pulmonary disease. Disease-a-Month 33(2): 66-120.

7. Hardy, K.A., Schidlow, D.V., Zaeri, N.,1988. Obliterative bronchiolitis in children. Chest 93 (3): 460-466.

8. Kane, Y., Diop, A., Isselmon, E., Kaboret, Y., Ould, M.M., Diallo, B.C., Kane, Y., Kadja, M.C., BadaAlambedji, R., Bezeid, O.E., Akakpo, J.A., Kaboret, Y., 2005. Lung lesions and bacteria of the onehumped camel (Camelus dromedarius) at Nouakchott slaughterhouse in Mauritania. Revue d Élevage et de Médeci Véterinaire de. Pays. Tropicaux. 58:145-150.

9. Kelly, F.L., Sun, J., Fischer, B.M., Voynow, J.A. Kummarapurugu, A.B., Zhang, H.L., Nugent, J.L., Beasley, R.F., Martinu, T., Gwinn, W.M., Morgan, D.L., Palmer, S.M., 2014. Diacetyl Induces Amphiregulin Shedding in Pulmonary Epithelial Cells and in Experimental Bronchiolitis Obliterans. Am J Respir Cell Mol Biol 51(4): 568-574.
10. Kirchner, B. K., Port, C. D., Magoc, T. J., Sidor, M. A., Ruben, Z., 1990. Spontaneous bronchopneumonia in laboratory dogs infected with untyped Mycoplasma spp. Laboratory Animal Science 40 (6): 625-628.

11. Kurland, G. and Michelson, P., 2005. Bronchiolitis obliterans in children. Pediatric Pulmonology 39 (3): 193-208.

12. Li, X., Botts, S., Morton, D., Knickerbocker, M. J., Adler, R., 2006. Oleic acid-associated bronchiolitis obliterans organizing pneumonia in beagle dogs. Veterinary Pathology 43 (2) :183-185.

13. Neurohr, C., Huppmann, P., Leuchte, H., Schwaiblmair, M., Bittmann, I., Jaeger, G., Hatz, R., Frey, L., Uberfuhr, P., Reichart, B., Behr, J., 2005. Munich Lung Transplant Group. Human herpesvirus 6 in broncho alveolar lavage fluid after lung transplantation: a risk factor for bronchiolitis obliterans syndrome. Am J Transplant 5(12):2982-91 .

14. Philippou, S., Otto, P., Reinhold, P., Elschner, M., Streckert, H. J., 2000. Respiratory syncytial virusinduced chronic bronchiolitis in experimentally infected calves. Virchows Archiv 436 (6): 617-621.

15. Poletti, V., Casoni, G., Ravaglia, C., Romagnoli, M.,Tomassetti, S., 2015. Bronchoalveolar lavage. Technical notes. Monaldi Archives for Chest Disease 75 (1): $42-43$.

16. Quan, S. F., Lemen, R. J., Witten, M. L, Sherrill, D. L. , Grad, R, Sobonya, R. E., Ray C. G.,1990.Changes in lung mechanics and reactivity with age after viral bronchiolitis in beagle puppies. Journal of Applied Physiology 69 (6): 2034-2042.

17. Silvija-Pera Jerkic, Folke Brinkmann, Alistair Calder, Alicia Casey, Megan Dishop, Matthias Griese, Geoffrey Kurland, Mandy Niemitz, Sylvia Nyilas, Dirk Schramm, Ralf Schubert, Michael Tamm, Stefan Zielen, Martin Rosewich, 2020. Postinfectious Bronchiolitis Obliterans in Children: Diagnostic Workup and Therapeutic Options: A Workshop Report. Canadian Respiratory Journal 2020 (30): 1 16.

18. Vilchez, R.A., Dauber, J., McCurry, K., Iacono, A., Kusne, S., 3003. Parainfluenza virus infection in adult lung transplant recipients: an emergent clinical syndrome with implications on allograft function. Am J Transplant 3:116-20.

19. Wylie, S.L., Langlois, D., Carey, S, Nelson, N.C., Williams, K.J., 2019. Constrictive Bronchiolitis Obliterans in a Dog. 2019. Case Reports. J Am Anim Hosp Assoc 55(2): e55201.

20. Zubair, R., Khan, A.M.Z., Sabri, M.A., 2004. Pathology of camel lungs. Journal of Camel Sciences 1:103-106. 